\title{
Science in Industry
}

$\mathrm{T}$ HE twenty-second report of the Department of Scientific and Industrial Research*, which covers the period October 1, 1936-September 30, 1937, includes the report of the Committee of the Privy Council signed by Lord Halifax, and the longer report of the Advisory Council signed by Lord Riverdale, together with a summary of the work of the National Physical Laboratory and other research stations and research boards and brief reports from the various research associations. Both the report of the Advisory Council and of the Committee of the Privy Council pay tribute to the work of Lord Rutherford, whose last act as chairman of the Advisory Council was to shape the report which is now submitted. The present report once more displays the impressive contribution which the work of the Department makes to every aspect of our national life.

The expenditure of the Department in 1936-37 was $£ 830,180$ gross or $£ 583,230$ net as against $£ 571,831$ net in $1935-36$. The largest single item of expenditure was $£ 105,589$ on the National Physical Laboratory, compared with $£ 109,038$ in 1935-36, the gross expenditure of $£ 244,081$ covering, however, the cost of work carried out at the laboratories of the Food Investigation Board, the Radio Research Board, the Road Research Board and other research boards of the Department. Against this gross total, receipts amounted to $£ 138,492$, of which $£ 67,863$ represents foes from industry for paid work. The total receipts from industry for the work of the Department, including contributions to co-operative research, amounted to $£ 106,250$, while a further $£ 77,101$ was received from other Government Departments for services rendered, $£ 35,035$ from the Road Fund and $£ 9,543$ from the Empire overseas for food investigation. Expenditure on fuel research was $£ 105,660$ gross or $£ 92,809$ net, on building and road research $£ 87,957$ gross or $£ 32,264$ net, on the Chemical Research Laboratory $£ 21,146$ net, on forest products research $£ 39,382$ net and on the Geological Survey and Museum $£ 68,449$. Almost the whole of the expenditure of $£ 10,613$ on water pollution research was covered by receipts amounting to $£ 9,215$, while $£ 15,928$ was received against the gross expenditure of $£ 54,926$ on food investigation. Grants to research associations, etc., amounted to $£ 126,510$ as against $£ 108,951$ in $1935-36$ and $£ 85,384$ in $1934-35$, and the report notes the formation of a new Research Association

* Department of Scientific and Industrial Research. Report for the Year 1936-37. (Cmd. 5647.) Pp. iv +195. (London: H.M. Stationery Office, 1938.) 38 . net. by the Pottery Manufacturers' Federation, to which the Department has made an annual grant of $£ 5,000$.

Special stress is laid in the report of the Advisory Council on the work of the Water Pollution Research Board, which has now completed ten years work and in that time has succeeded to a remarkable extent in bringing about a realization of the community of interest in all concerned and in establishing scientific research as the true servant of all parties. The intensive survey of the River Tees and of the effects of the discharge into it of large quantities of sewage and of industrial effluents has led to the discovery that the true cause of the killing of smelts in the estuary is cyanide in coke-oven effluent. Further, it has been found that this cyanide can be readily converted into the much less toxic ferrocyanide if it is treated with spent pickle liquor and lime. At the same time, the suggestion has been put forward that modified methods for cooling and washing cokeoven gas and the use of any remaining waste waters to quench coke would greatly reduce the quantity of the discharge. This suggestion has already been followed in a large installation of coke ovens recently erected at South Bank on the Tees.

This notable survey, with its demonstration of the possibility of reconciling the community's requirements in regard to pure water supply and the industrial disposal of effluent, has already led to a further investigation of the effect of crude sewage discharge on the navigability of the Mersey, which has just been completed. Successful work has also been carried out on the treatment of effluent from beet-sugar factories and from large dairies, while at the Chemical Research Laboratory the Board has sponsored studies of the softening of water, in which certain synthetic resins have given promising results.

This review of the work on water pollution well illustrates the cumulative effect of such investigations as a body of knowledge is built up which can be readily applied to the solution of allied problems as they arise, and the recent typhoid epidemics at Croydon and elsewhere emphasizes the importance of constant scientific control if a pure water supply is to be secured. So, too, in the field of atmospheric pollution the Department is steadily acquiring scientific data on the extent and distribution of pollution and is making a special survey of the city of Leicester which should ultimately provide the basis for effective action to 
diminish the toll at present taken of health and general welfare in industrial centres by this cause.

Passing from water supply and air to food supply, we find the Department making equally significant contributions. The researches of the Food Investigation Board have ranged, for example, from the study of storage problems such as the value of ultra-violet light in prolonging the storage-life of meat, the effect of the concentration of carbon dioxide in the atmosphere in which eggs are stored, the diminution of 'store-burn' in the storage of poultry, the cold storage of herrings, the gasstorage of pears, strawberries and other fruits, to the chemical composition of wood smoke used in curing fish, the effect of muscular exertion on the chemical composition of muscular tissue and the keeping quality of bacon. Further trials have confirmed that freshly caught white fish can be brine frozen, glazed and stored so that after four to six months the fish is highly palatable, suitable for smoke curing and substantially unchanged. Of special interest are the results obtained from a further scientific expedition to Australia and New Zealand to study the performance of the new 'jacket' system of refrigeration developed at the Ditton Laboratory of the Department. The full data obtained are still being examined, but the new system appears to be working satisfactorily. In the great bulk of a stack of 50,000 cases of apples the temperature was uniform within $0.5^{\circ} \mathrm{F}$., and with the new system about 3,000 more cases could be carried than with normal storage.

The bearing of these results on food supply and particularly in view of the increased importance of storage questions should be obvious to all whether in relation to national defence or to the questions of quality or public health. Equally important work is, however, being carried out in this field by a number of research associations. The Research Association of British Flour Millers has succeeded in developing a machine for measuring and recording graphically the baking quality of flours and a full-scale plant has now been erected for improving the baking quality of flour and the crumb quality of the bread by treatment with hot damp air according to the process developed in 1928. Other investigations of the Association have related to the nutritive value of bread and the place of bread in the dietary. The Research Association for the Cocoa, Chocolate, Sugar Confectionery and Jam Trades has investigated the resistance of cacao butter to oxidation changes with the view of avoiding the stale flavours associated with such changes, as well as the mechanism of pectin jelly formation by fruits, and is making a special study of toffee manufacture as well as of the protection of cacao beans, nuts, dried fruits, etc., against storage pests. The Food
Manufacturers Research Association has been responsible for investigations on the curing of bacon by a new method, the quality of gelatin used for meat products in glass cases, and the cause of white deposits on fish preserved raw by packing in salt.

Turning from food supply to fuel and lighting we find an equally impressive record of service rendered to daily needs. Besides the physical and chemical survey of the national coal resources and the study of the hydrogenation of coal with its bearing on the more effective utilization of coal whether primarily as fuel, as motor spirit or as lubricating oil, the work of the Fuel Research Board is making such incidental contributions as the study of possible improvements to the domestic grate, particularly from the point of view of smoke reduction and increased efficiency and the preparation of coal for the market including its 'dustproofing' to eliminate the raising of dust when the coal is handled. In the field of lighting, the work of the Department touches the life of the ordinary citizen at many points both inside his home and out. Besides, for example, the investigations on daylight problems in clerical work and on the relative merits of light of different colours for various visual tasks, or the work of the National Physical Laboratory on the standardization of electric lamps, the work of the Department in this field has had a most important bearing on road safety. A report issued by the Department has shown that the claims made for a coloured headlight beam for motor-cars in place of a white beam cannot be substantiated, while an investigation concerned with the question of the best colour for street lighting has led to the development of a photographic means of reproducing the actual street scene in all the details affecting an observer's ability to pick out objects in the street which appear and disappear on the surface of the lighted street.

The motorist will indeed find much else that is of interest in the work of the Department, for the Road Research Board's investigations cover such problems as that of skidding, the testing of road surfacing materials, the stresses imposed by all kinds of tyres. For the study of skidding an ingenious apparatus has been developed for taking surface texture prints of a road, while another ingenious apparatus the 'wet road clock' has been developed for recording the periods during which a road was wet, in carrying out tests on the durability of a road. At the National Physical Laboratory, the Department is investigating, too, the noise of motor horns with the object of correlating offensiveness with special physical features, and important research on cylinder wear initiated by the Department in co-operation with the Institution of Automobile Engineers is nearing 
completion, while the Research Association of British Rubber Manufacturers has completed an investigation on the ageing of the inner tubes of motor tyres, in which the accelerated tests of ageing have been correlated with natural ageing.

The work of the Building Research Station makes many important contributions to the comfort of the home, both indirectly in its fundamental studies of the properties of building materials such as cement, asphalt, limes and plasters, bricks, roofing tiles, etc., all of which ultimately lead to the construction of more satisfactory houses and also through its studies on the efficiency of buildings from the point of view of the user. The new heating laboratory has carried out extensive tests with hot water radiators as well as on heat transmission through walls and the thermal conductance of windows and a definite programme of work on ventilation has also been undertaken, while jointly with the National Physical Laboratory the Station has initiated an investigation into the subject of noise in flats. Of equal importance to the householder from this point of view is some of the work of the research associations such as that of the British Non-Ferrous Metals Research Association the investigations of which have thrown much light on the corrosion in hot water installations in which copper circulating pipes and galvanized tanks are used in the same system. Experimental work on underground corrosion of lead water pipes, cable sheaths, etc., has also been initiated by the same Association, while the British Electrical and Allied Industries Research Association is making important contributions to public safety and comfort by its detailed investigations of fire risks associated with electrical plant, the protection of overhead lines against lightning by more efficient earthing and the properties required in overhead line wires, and the means of eliminating transformer noise. Again, the work of the Research Association of British Rubber Manufacturers on rubber floorings has led to the preparation of an appropriate British Standard Specification which should assist the general public to obtain a satisfactory article.

Other work carried out at the Building Research Station such as that concerned with methods of cleaning stonework with water without hard scrubbing, where a very promising process is now being tried, or on the failure of paints, bears directly on the amenities of buildings, and in this field the Research Association of British Paint, Colour and Varnish Manufacturers is also making important contributions often in direct co-operation with the Building Research Station. Conclusions from work on the preservation of iron and steel by means of paint have recently been consolidated in relation to practical needs.
No less interesting, however, is the work of the Department which touches upon questions of clothing, whether indirectly, as in the investigations of the British Cotton Industry Research Association on the sizing of rayon warps or on the spinning and cleaning of cotton or in those of the Wool Industries Research Association on the problems arising out of the treatment of wool to confer resistance to shrinkage which has led to a new process for reducing shrinkage, or directly, as in the studies of the British Launderers' Research Association on the washing of woollens or the fundamental properties of detergents. Mention can here only be made further of the Wool Industries Research Association's investigations on substitutes for olive oil for oiling wool, prompted by the shortage of supplies consequent upon the Spanish Civil War, and on the use of rubber in conjunction with wool ; to that of the Linen Industry Research Association on spinning a new type of linen yarn ; and to that of the British Boot, Shoe and Allied Trades Research Association on walking research, in which good progress has already been made in what is really a long range research. A number of interesting side issues are also being explored. For example, the importance of flexibility in the work has led to the development of a flexibility meter for measuring the flexibility of shoes and another machine is being developed to put shoes through the motions of walking and give soles the treatment they receive during wear so as to obtain an insight into the best combinations of materials and constructions to give maximum durability. In addition, the question of occupational footwear has come to the front during the year, and the Association is giving attention to the design and specification of boots and shoes for different occupations.

It is impossible to go into greater detail into the ways in which the Department, whether through the Research Associations or its special Research Stations or Boards, ministers to our daily needs. If the ordinary citizen is perhaps most likely to be interested in motoring as a means of transport, other forms of transport are equally served by the Department. Reference has already been made to research on the transport of food in storage by sea. Even more fundamental contributions to the design of all classes of ships are made in the William Froude Laboratory at the National Physical Laboratory, where a record number of ship designs were tested. Of the $1,180,000$ tons of merchant shipping the construction of which was commenced in Great Britain in 1936, 78 per cent was based on tests in this Laboratory. Experimental work on the influence of waves on the resistance, propulsion and pitching of ships is already leading to improvements in design of different types of ship, 
while in the Aerodynamics Department of the National Physical Laboratory not only are new types of aircraft being tested but also important work bearing on the safety of flight has been carried out.

The National Physical Laboratory renders such significant assistance to the work of so many research associations and Government departments, quite apart from its direct scientific assistance to industry that it forms something of a keystone in the structure or organization of the Department. Nor should it be forgotten that much of the less spectacular work, whether in the collection of and dissemination of information, the testing and establishment of standards is of no less importance than work leading to advances or developments which catch the public eye. Indeed, without the foundation of knowledge thus accumulated and the network of services thus established, it is highly improbable that such advances and the important savings to industry and the community which have accrued from the work of the Department would have been achieved to anything like the same extent. The magnitude of these savings can only be illustrated here by reference to one example. The forty to forty-four per cent improvement in efficiency in steam-generating stations in the last two years is attributed largely to the work of the Electrical Industries Research Association, and on the output of units sold in 1935, the higher efficiency represents a saving in coal of more than $£ 7,000,000$. Even only ten per cent of this sum exceeds the total annual expenditure of the Association on all its researches, and it is doubtful whether any other expenditure in the national budget brings in anything like the same return as the $£ 600,000$ expended by the Depart. ment of Scientific and Industrial Research.

\section{Relics of the Mt. Pele Eruption of May 8, I902}

\section{By Dr. C. T. Trechmann}

$\mathrm{T}$ HE uncouth and sinister-looking volcano of Mt. Pelé (or La Montagne Pelée) occupies the north end of Martinique and rises to about $4,400 \mathrm{ft}$. The rest of the island consists of lavas, tuffs and limestones which have yielded a fauna of Miocene, probably of Helvetian age. Mt. Pelé had minor eruptions in 1792 and 1852 , but began to give warning near the end of April 1902. The great eruption or nuée ardente came at 8 p.m. on May 8, 1902. St. Pierre, the one-time capital of the island, with thirty to forty thousand inhabitants, six miles south of the volcano and just within the triangular zone of destruction, was overwhelmed. Further destructive nuées occurred during 1902 and 1903, and they were renewed during 1929 and 1930, when avalanches of incandescent stones, some of them as large as haystacks, were projected down to the sea at the Rivière Blanche.

Perret defines a nuée ardente as an "avalanche of an exceedingly dense mass of hot, highly gascharged and constantly gas-emitting fragmental lava, much of it finely divided, extraordinarily mobile, and practically frictionless, because each particle is separated from its neighbours by a cushion of compressed gas."

The well-known spike or spine of hypersthene andesite which was protruded from the summit first appeared about November 3, 1902, but had fallen to pieces by July 1903 . It was grooved on one side through squeezing against the sides of the aperture, and reached a height of $900 \mathrm{ft}$. An eyewitness at Morne Rouge said there were seven luminous points on the volcano's side just before it burst. This seems to indicate that gases were rapidly melting their way through the side of the cone.

These scorched and melted relics have often been attributed in part to the conflagration that burnt up the town after the eruption, but Perret records that bottles were softened and green mangoes converted to charcoal in places where no conflagration occurred. He also records that barefooted negroes entered the town on the afternoon of the day of the eruption, and photographs show quantities of wood and trees in all parts except those nearest the volcano. Reports of the conflagration are probably exaggerated. The sudden rain of intensely hot ashes would probably immediately drive off or distil a great volume of inflammable gas from the large quantities of rum, oil, wood, sugar, coal, etc., stored in the city and this would ignite immediately in contact with the oxygen outside the erupted gases. The only one of the seventeen ships in the bay that got away was the Roddam. Part of her cargo consisted of what appears to be china clay; this has been baked to brick and sprinkled with ash, which has combined with the material to form spots of brown melt.

We may safely conclude, therefore, that it was the direct action of the nuée that brought about 